University for Business and Technology in Kosovo

UBT Knowledge Center

UBT International Conference

2013 UBT International Conference

Nov 1st, 4:30 PM - 4:45 PM

\title{
Pervious Concrete-New Solution for Sustainable Urban Street Construction Case: Prishtina and Tirana
}

Driton R. Kryeziu

University for Business and Technology

Mevlan Qafleshi

Polytechnic University of Tirana

Fisnik Kadiu

Polytechnic University of Tirana

Follow this and additional works at: https://knowledgecenter.ubt-uni.net/conference

Part of the Architecture Commons

\section{Recommended Citation}

Kryeziu, Driton R.; Qafleshi, Mevlan; and Kadiu, Fisnik, "Pervious Concrete-New Solution for Sustainable Urban Street Construction Case: Prishtina and Tirana" (2013). UBT International Conference. 8.

https://knowledgecenter.ubt-uni.net/conference/2013/all-events/8

This Event is brought to you for free and open access by the Publication and Journals at UBT Knowledge Center. It has been accepted for inclusion in UBT International Conference by an authorized administrator of UBT Knowledge Center. For more information, please contact knowledge.center@ubt-uni.net. 


\title{
Pervious Concrete-New Solution for Sustainable Urban Street Construction Case: Prishtina and Tirana
}

\author{
Driton R. Kryeziu ${ }^{1}$, Mevlan Qafleshi², Fisnik Kadiu ${ }^{3}$ \\ ${ }^{1}$ University for Business and Technology, Faculty for Architecture, \\ Prishtinë, Kosova \\ ${ }^{2}$ Faculty of Mathematical Engineering \& Physical Engineering, Polytechnic University of Tirana, \\ Tirana, Albania \\ ${ }^{3}$ Civil Engineering Faculty, Tirana, Albania
}

\begin{abstract}
Great problems resulting from the rainfalls, or saying explicitly: The water runoff on roads, streets, pavements, parking lots, squares, etc., require solutions. We are all witnesses of how streets of Prishtina and Tirana look like during rainfalls. Each one of us has been in one or other way participants in any of these occurrences, whether as pedestrians, vehicle operators or passengers. What was your impression and answer to it? The main goal of preparing this paper consists in a solution that would result as ideal perfection in preventing and avoiding entirely the urban water runoff and floods, the consequences of heavy rainfalls that last for long periods of time with stormy showers. The solution as per this study would be the utilization of pervious concrete. Pervious concrete is a construction material featuring the property that all water falling onto its surface to pass through it and be drained to the bottomside and flowing underground. This is enabled due to its composition and porous structure, accordingly all water-rain falling onto it will be drained and the surface remains water-free and easily passable. Pervious concrete, having the property of draining the water, has a positive impact on drivers steering the vehicles by the effect: no water-moisture on the roads, no vehicle sliding. Many countries all over the world apply this, especially in the USA where the application of pervious concrete has been applied for more than 40 years owing to innovative requirements of the American Government and awareness of employers, constructers, designers, urbanismarchitects on the advantages and benefits of pervious concrete. By the application of pervious concrete, the streets and roads of Prishtina and Tirana will not be flooded anymore, the pedestrians would be able to walk comfortably during wet weather conditions, the traffic flow will not be obstructed and stopped, and owing to its high porous structure this application will have a positive impact in lessening the acoustic pollution being as one of the major problems of urban sites.
\end{abstract}

Keywords: Pervious concrete; sustainable street; environment; storm water, porosity, durability, etc.

\section{Introduction}

\subsection{Generals on Pervious Concrete}

Pervious Concrete has been around for hundreds of years. The Europeans recognized the insulating properties in structural pervious concrete for their buildings constructions. Europeans have also used pervious concrete for paving including on the Autobahn (eng-Highways). Stories passed down through the years tell us that our soldiers didn't mind walking on pervious roads during World War II because it meant their feet would be dry! [1].

In the 1960s, when pervious concrete pavement first made its appearance in North America, it simply didn't catch on widely. Over the next several decades, while there were many installations of these pavements, they were localized to certain regions. In today's environmentally conscious climate, the benefits of pervious concrete to sustainability have reinvigorated interest in these free-draining 
pavements. And though it's appealing for its technical benefits, pervious concrete hasn't necessarily been attractive...until now. Renewed attention to pervious pavements has led some people to experiment with improvement of the surface aesthetics - and spawned a new type of concrete sometimes referred to as "architectural pervious concrete" (APC).

Pervious concrete pavement has been used for over 30 years in England and the United States (Youngs 2005; Maynard 1970). PCPC is also widely used in Europe and Japan for roadway applications as a surface course to improve skid resistance and reduce traffic noise (Beeldens 2001; Kajio et al. 1998). Currently, full-depth PCPC is used in the United States for parking lots, pathways, and, in some cases, low-volume roads for storm water applications (Tennis et al. 2004) [2]. This Concrete has the feature of very high permeability, very suitable for parking lots, sidewalks, driveways, greenhouse floors or low-speed applications such as golf course paths and residential streets, tennis courts, patios, slope stabilization, swimming pool decks, , zoo areas, shoulders, drains, noise barriers, friction course for highway pavements, permeable based under a normal concrete pavement. Pervious concrete is generally not used solely for concrete pavements for high traffic and heavy wheel loads [3]. Pervious concrete is an innovative building material with many environmental, economic, and structural advantages. The proper utilization of pervious concrete is a recognized Best Management Practice by the U.S. Environmental Protection Agency (EPA) for providing first-flush pollution control and storm water management. Property owners and developers can also reduce fees and enhance the bottomline by using pervious concrete, which commonly provides 20-40 years of service with little or no maintenance [5], [16].Pervious concrete is a high porosity concrete used for outdoor flatwork that allows water to pass through it. It is a low water/cement ratio, low-slump mix consisting of cement, narrowly graded coarse aggregate, little or no fine aggregate, water and admixtures. It is held together by cementations paste at the coarse aggregate contact points since there is limited paste and fine aggregate to fill the voids between the coarse aggregate [2].

Pervious concrete - a zero slump mix that allows rainwater to pass through the pavement and into the underlying soil at an astonishing rate of 100 to 750 liters per minute per square meter. This is also referred to as "no-fines concrete" or "porous concrete," this material is a simple mix of coarse aggregate, cementations materials, water, and in some cases, fibers for binding. Carefully controlled amounts of water and cementations materials are used to create a paste that forms a thick coating around aggregate particles without flowing off during mixing and placing. Using just enough paste to coat the particles maintains a system of interconnected voids in the order of $15 \%$ to $35 \%$ depending on materials and intended application. Pervious concrete is one of the hottest topics in global development today. As owners, architects, land developers, and concrete professionals become familiar with its benefits, the interest in pervious concrete continues to grow. The use of pervious concrete pavements provides a solution to new requirements under Environmental Protection Agencies regulations that call for decreasing the amount of surface water runoff and initially treating the runoff.

\subsection{Applications Review}

Although not a new technology, in the USA, (it was first used in 1852 (Ghafoori and Dutta 1995)), pervious concrete has received renewed interest, partly because of Federal Clean Water Legislation in the USA. The US Environmental Protection Agency's (EPA) Phase II Final Rule requires the operators of all municipalities in urban areas to develop, implement, and enforce a program to reduce pollutants in post-construction runoff from new development and redevelopment projects that result in the land disturbance of greater than or equal to 1 acre. The above is a requirement in order to attain a National Pollutant Discharge Elimination System (NPDES) permit. Among other things the municipalities are required to develop and implement strategies which include a combination of structural and /or nonstructural best management practices (BMPs) [3], [13].

Pervious concrete pavement is recognized as a Structural Infiltration BMP by the EPA for providing first flush pollution control and storm water management. In addition to federal regulations there has been a strong move in the USA towards sustainable development. Sustainable development is development that meets the needs of the present generation without compromising the needs of future generations. In the US the US Green Building Council (USGBC) through its Leadership in Energy and Environmental Design (LEED) Green Building Rating System fosters sustainable construction of buildings. Projects are awarded Certified, Silver, Gold, or Platinum certification depending on the number of credits they achieve. 
Pervious concrete pavement qualifies for LEED credits and is therefore sought by owners desiring a high LEED certification.As regulations further limit storm water runoff, it is becoming more expensive for property owners to develop real es tate, due to the size and expense of the necessary drainage systems. Pervious concrete paving reduces the runoff from paved areas, which reduces the need for separate storm water retention ponds and allows the use of smaller capacity storm sewers. This allows property owners to develop a larger area of available property at a lower cost. Pervious concrete also naturally filters storm water and can reduce pollutant loads entering into streams, ponds and rivers. It capture s the first flush of rainfall (the first 30 to minutes of rainfall which will lead to a runoff with most pollutants) and allows that to percolate into the ground, so that soil chemistry and biology can treat the polluted water. Pervious concrete functions like a storm water retention basin and allows the storm water to infiltrate the soil over a large area, thus facilitating recharge of precious groundwater supplies locally. All of these benefits lead to more effective land use. Pervious concrete can also reduce the impact of development on trees. A pervious concrete pavement allows the transfer of both water and air to root systems allowing trees to flourish even in highly developed areas [3], [10], [13].

\section{Ultra-Urban Areas}

Ultra-urban areas are densely developed urban areas in which pervious and naturally draining surface area is reduced. Pervious concrete pavements are a good option in these areas because they allow for additional use of land by eliminating the need for storm water retention systems.

In three last decades in Tirana, respectively two in Prishtina we are facing a rapid urban development. Random constructions, without detailed urban design of multi stories buildings has resulted with a chaotic urban and architectural state. Many times we witness events of water-runoffs and storms on our streets and other areas built with conventional materials: asphalt, normal concrete, paving blocks, etc. during rainfalls. This needs to cope with. In mitigating this, the Pervious Concrete is, if not the only, is the best solution.

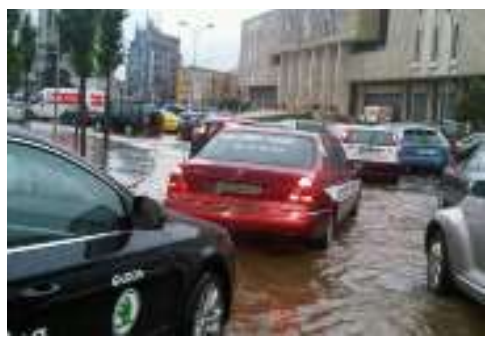

a) Tirana after rainfall

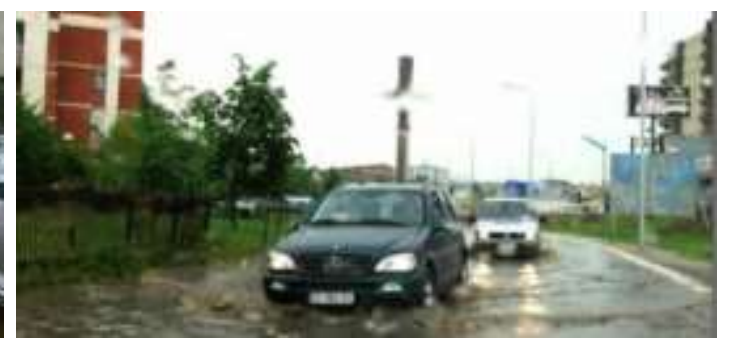

b) Prishtina after rainfall

Fig. 1. Images of Tirana and Prishtina during overfloods.

As mentioned before, in many countries this is already applied. So we can proceed this to solving our problems: Ideal application for pervious concrete pavement is around buildings (walkways, courtyards, etc.) and parking areas, as well as low-volume roadways. Pervious concrete pavement may also have some application on highways, where it could be used in shoulder and median construction for storm water runoff mitigation. There may also be application for its use as a surface material to reduce hydroplaning, splash and spray, and mitigate tire-pavement noise.

Additionally, we can apply the PC for sidewalks and replacing the concrete culverts with PC, as shown in Fig 2. 


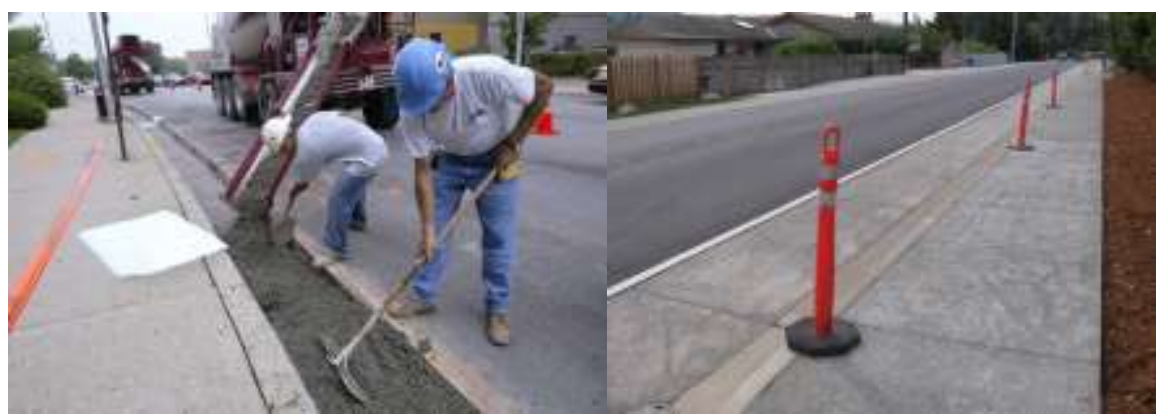

Fig. 2. Application of Pervious Concrete in construction of sidewalks and culvert.
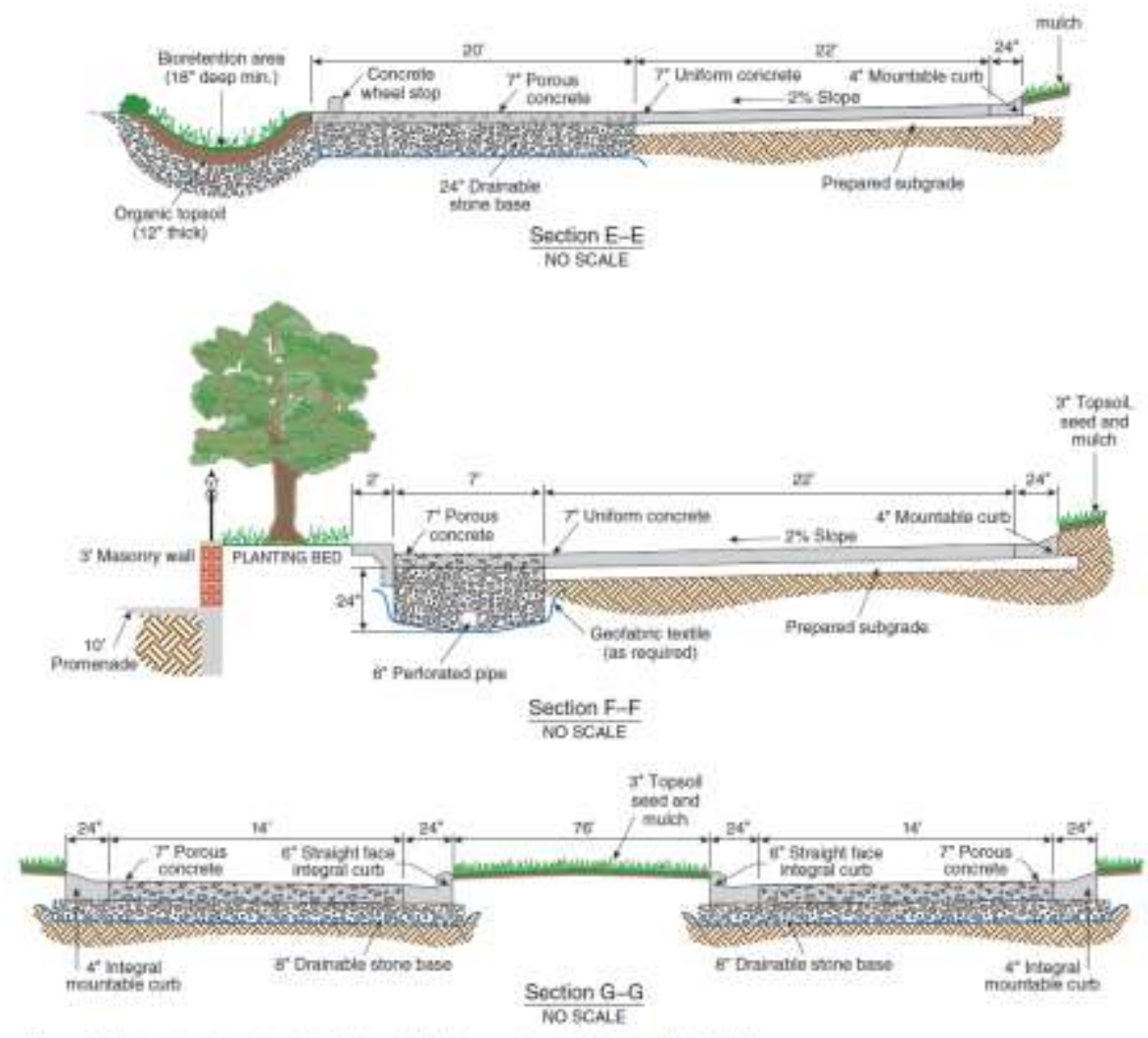

Fig. 3. Optional solution for applications of Pervious Concrete

Source. Illustrations from the Lost Peninsula Marina project in Erie Township, Michigan.

\section{Materials and Properties}

Pervious concrete, also known as porous, gap-graded, permeable, or enhanced porosity concrete, mainly consists of normal Portland cement, coarse aggregate, water and additives. In normal concrete the fine aggregates typically fill in the voids between the coarse aggregates. In pervious concrete fine aggregate is nonexistent or present in very small amounts. Also there is insufficient paste to fill the remaining voids with the result that pervious concrete has porosity anywhere from 15 to $35 \%$ but most frequently about 20\% [3]. Aggregate could be of river origin or crushed and depends on the type of required surface texture. 
Aggregate grading used in pervious concrete are typically either single-sized coarse aggregate or grading between $2 / 4,4 / 8$ and $8 / 16 \mathrm{~mm}$. $(2 / 4,4 / 8$ and $8 / 11.2 \mathrm{~mm})$, i.e. no fines.

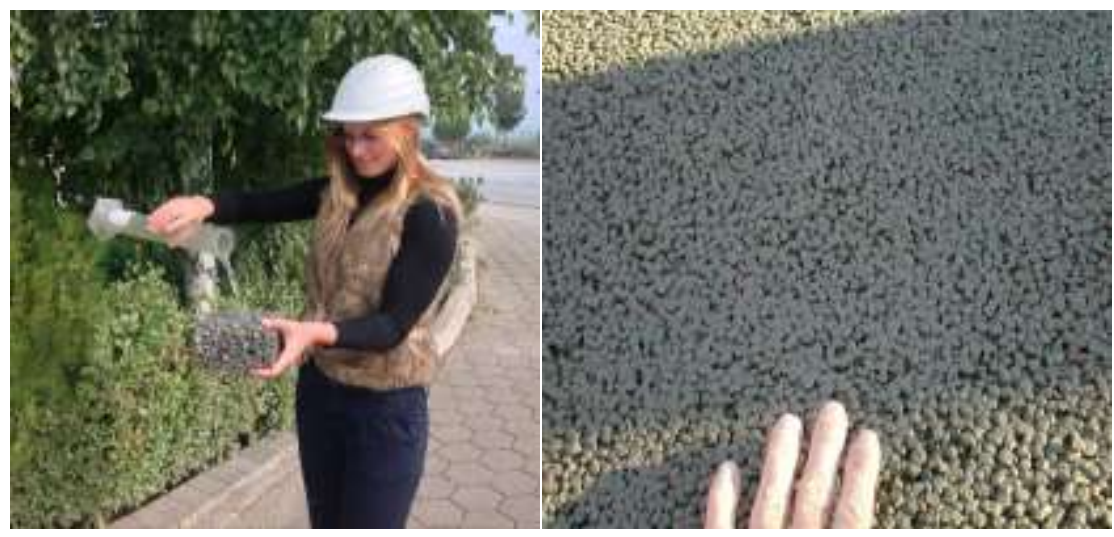
a), PC, aggregate used $2 / 16 \mathrm{~mm}$
b), PC, aggregate used 2/11.2 mm

Fig. 4. Pervious Concrete of various textures

All types of cementations materials conforming to their EN 197-1 specifications can been used. Pervious concrete can be made without chemical admixtures, but it is not uncommon to find several types of chemical admixtures added to influence the performance in a favorable manner. [21]. Due to the weather conditions in Tirana, Pervious Concrete may be applied without any admixtures for improving freezethaw cycles resistance. Prishtina is the opposite case; This implies the use of air entering admixtures either chemical or mineralogical as plasticizers, retarders, accelerators or Silica fume, Fly Ash, Powder, etc.

Table. 1 shows mix proportioning for pervious concrete. Contrary to possible intuitive thinking that this kind of mix may lead to weak concrete, it has been shown that pervious concrete exhibits flexural strength in the 1.0 3.8 MPa and compressive strength in the 3.5 28.0 MPa range. [24].

Table 1. Typical* Ranges of Materials Proportions in Pervious Concrete**

\begin{tabular}{|c|c|}
\hline Cementitious materials & 270 to $415 \mathrm{~kg} / \mathrm{m}^{3}\left(450\right.$ to $\left.700 \mathrm{lb} / \mathrm{yd}^{3}\right)$ \\
\hline Aggregate & 1190 to $1480 \mathrm{~kg} / \mathrm{m}^{3}$ (2000 to $\left.2500 \mathrm{lb} / \mathrm{yd}^{3}\right)$ \\
\hline Water-cement ratio (by mass) & 0.27 to $0.303 * * *$ \\
\hline Aggregate-cement ratio (by mass) & 4 to $4.5 / 1 * * *$ \\
\hline Fine-coarse aggregate ratio (by mass) & 0 to $1 / 1 * * * *$ \\
\hline
\end{tabular}

* These proportions are given for information only.

** Chemical admixtures, particularly retarders and hydration stabilizers, are also commonly used.

Use of supplementary cementations materials, such as fly ash and slag, is common as well.

*** Higher ratios have been used, but reductions in strength and durability may result.

****Addition of fine aggregate will decrease the void content and increase strength.

(Source: http://www.secement.org/PDFs/ct043[1].pdf

Table 2. shows the typical properties of pervious concrete mixtures. This table is intended to be a guide; particular mixtures should be trial batched to determine properties prior to use. Often, concrete producers will have experience with mixture designs based on available materials and can provide guidance. ACI Committee 522 is preparing a comprehensive document on pervious concrete. [24]. 
Table 2. Technical Properties of Pervious Concrete

\begin{tabular}{ll}
\hline Property & Typical Values \\
\hline Slump & $20 \mathrm{~mm}$ \\
Density (unit weight) & 1600 to $2000 \mathrm{~kg} / \mathrm{m}^{3}$ \\
Setting time & $1 \mathrm{hour}$ \\
Porosity & $15 \%$ to $25 \%$ by volume \\
Permeability (flow rate) & $120 \mathrm{~L} / \mathrm{m}^{2} / \mathrm{min}$ to $320 \mathrm{~L} / \mathrm{m}^{2} / \mathrm{min}^{* *}$ \\
Compressive strength & $3.5 \mathrm{MPa}$ to $28 \mathrm{MPa}$ \\
Flexural strength & $1 \mathrm{MPa}$ to $3.8 \mathrm{MPa}$ \\
Shrinkage & $200 \times 10^{-6}$ \\
\hline
\end{tabular}

* May be extended to as much as 2.5 hours with chemical admixtures.

** Laboratory mixtures with flow rates as high as $700 \mathrm{~L} / \mathrm{m}^{2} / \mathrm{min}$ have been prepared.
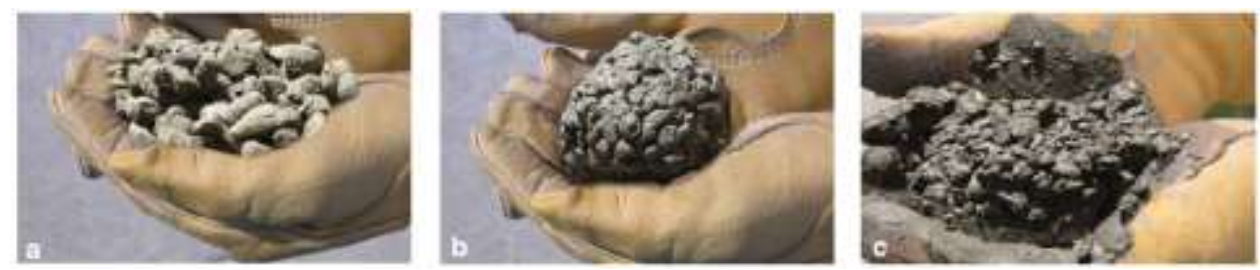

Fig. 5. Samples of pervious concrete with different water contents formed into a ball:

(a) too little water, (b) proper amount of water, (c) too much water.

(Source: $\underline{\text { http://www.secement.org/PDFs/ct043[1].pdf }}$

\section{Mixture Proportioning}

Based on the results of many researches on Pervious Concrete and respective standards, we have designed three mix-Desing of PC.

In table 2. there are presented the physical and mechanical properties of our mix-Designs, that we have prepared in laboratory “ VELLEZERIT E BASHKUAR “ L.L.C. The compressive strength has been determined at the age of 2,7 and 28 days.

Materials used are of local origin: aggregate and powder from the quarry of " VELLEZERIT E BASHKUAR" L.L.C,

Cement, type CEM II 42,5 N, of SharrCem-Kosovo, Plasticizers from TKK Srpenica, Slovenia.

Table 3. Properties of the three Mix-Designs of Pervious Concrete

\begin{tabular}{llll}
\hline Property & \multicolumn{3}{c}{ Typical Values } \\
\hline & MIX-1 & MIX-2 & MIX-3 \\
Slump & $20(\mathrm{~mm})$ & $25(\mathrm{~mm})$ & $15(\mathrm{~mm})$ \\
Density (unit weight) & $1880\left(\mathrm{~kg} / \mathrm{m}^{3}\right)$ & $1810\left(\mathrm{~kg} / \mathrm{m}^{3}\right)$ & $1930\left(\mathrm{~kg} / \mathrm{m}^{3}\right)$ \\
Setting time & $70(\mathrm{~min})$ & $75(\mathrm{~min})$ & $105 *(\mathrm{~min})$ \\
Porosity & $20(\%)$ & $22(\%)$ & $18(\%)$ \\
Compressive strength & $7.2 \mathrm{MPa}, 2$ days & $6.5 \mathrm{MPa}, 2$ days & $8.8 \mathrm{MPa} 2$ days \\
& $16.9 \mathrm{MPa}, 7$ days & $14.4 \mathrm{MPa}, 7$ days & $18.1 \mathrm{MPa}, 7$ days \\
& $24.3 \mathrm{MPa}, 28$ days & $21.8 \mathrm{MPa}, 28$ days & $26.5 \mathrm{MPa}, 28$ days \\
\hline
\end{tabular}

* Admixture Cementol Delta Extra in this case has a higher dose, thus it is noticed a prolonged of setting time. 


\section{Construction Process}

\subsection{Pervious Pavement Design}

Two factors, which determine the design thickness of pervious pavements, are: the hydraulic properties, such as permeability and volume of voids, and the mechanical properties, such as strength and stiffness. Pervious concrete used in pavement systems must be designed to support the intended traffic load and contribute positively to the site-specific storm water management strategy. The designer selects the appropriate material properties, the appropriate pavement thickness, and other characteristics needed to meet the hydrological requirements and anticipated traffic loads simultaneously. Separate analyses are required for both the hydraulic and the structural requirements, and the larger of the two values for pavement thickness will determine the final design thickness [3]. [15].

\subsection{Hydraulic properties- Hydrologic Design}

In evaluating the hydrologic design capabilities of a pervious pavement, the approach is to determine whether the characteristics of the pervious concrete pavement system are sufficient to infiltrate, store, and release the expected inflow of water (which includes direct rainfall and may also include excess runoff from adjacent impervious surfaces). [22].

In essence, the hydrologic design of pervious concrete pavements should consider two possible conditions to ensure that excess surface runoff does not occur (Leming et al. 2007):

1. Low permeability of the pervious concrete material that is inadequate to capture the "first flush" of a rainfall event.

2. Inadequate retention provided in the pervious concrete structure (slab and subbase) [10].

Details on hydrologic design are beyond the scope of this document but are available in the literature (Leming et al. 2007; Wanielista et al. 2007; Rodden et al. 2011).

\subsection{Mechanical properties- Structural Pavement Design}

Pervious concrete is a unique material that has a matrixand behavior characteristics unlike conventional portland cement concrete or other pavement materials. Although these characteristics differ from conventional concretes, they are predictable and measurable.

Pervious concrete pavements can be designed using either a standard pavement procedure (AASHTO, WinPAS, PCAPAV, ACI 325.9R, or ACI 330R) or using structural numbers derived from a flexible pavement design procedure. Regardless of the procedure used, guidelines for roadbed (subgrade) soil properties, pervious concrete materials characteristics, and traffic loads should be considered. In the fig: 5 it is shown a typical cross section of pervious concrete pavement construction.

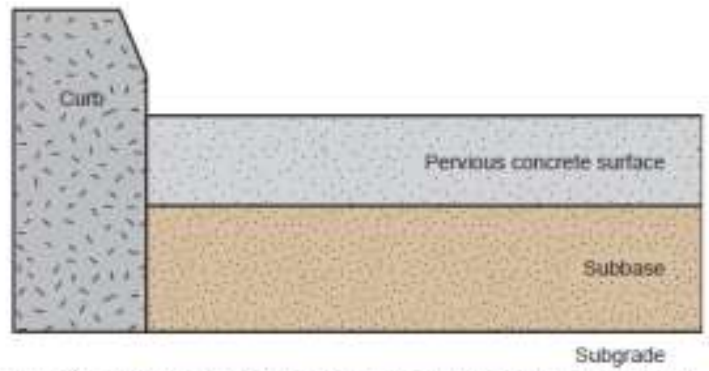

Fig. 6. Typical cross-section of pervious concrete pavement. Source: Tennis, et al, 2004, adapted from Paine 1990. 
Subgrade and subbase. In the design of pervious pavements, foundation support is typically characterized by a composite modulus of subgrade reaction, which should account for the effects of both the subgrade and the sub base. An open-graded sub base is commonly us ed beneath pervious concrete pavements not only to provide an avenue for vertical drainage of water to the subgrade, but a lso to provide storage capabilities. Special subgrade conditions (such as frost sus ceptibility or expansive soils) may require direct treatment.

Compressive strength. Pervious concrete mixtures can develop compressive strengths in the range of 500 psi to $4000 \mathrm{psi}(3.5 \mathrm{MPa}$ to $28 \mathrm{MPa}$ ), which is suitable for a wide range of applications. Typical values are about $2500 \mathrm{psi}(17 \mathrm{MPa})$. As with any concrete, the properties and combinations of specific materials, as well as placement techniques and environmental conditions, will dictate the actual in-place strength. Drilled cores are the best measure of in-place strengths, as compaction differences make cast cylinders less representative of field concrete. [16].

Concrete flexural strength. Flexural strength in pervious concretes generally ranges between about $150 \mathrm{psi}(1 \mathrm{MPa})$ and $550 \mathrm{psi}(3.8 \mathrm{MPa})$. Many factors influence the flexural strength, particularly degree of compaction, porosity, and the aggregate: cement $(\mathrm{A} / \mathrm{C})$ ratio.

The flexural strength of concrete is an important input in concrete pavement structural design. However, testing to determine the flexural strength of pervious concrete may be subject to high variability; therefore, it is common to measure compressive strengths and to use empirical relationships to estimate flexural strengths for use in design (Tennis et al. 2004).

Shrinkage. Drying shrinkage of pervious concrete develops sooner, but is much less than conventional concrete. Specific values will depend on the mixtures and materials used, but values on the order of 200 x 10 -6 have been reported (Malhotra 1976), roughly half that of conventional concrete mixtures. [20].

Freeze-Thaw Resistance. Freeze-thaw resistance of pervious concrete in the field appears to depend on the saturation level of the voids in the concrete at the time of freezing. In the field, it appears that the rapid draining characteristics of pervious concrete prevent saturation from occurring. Anecdotal evidence also suggests that snow-covered pervious concrete clears quicker, pos sibly because its voids allow the snow to thaw more quickly than it would on conventional pavements. In fact, several pervious concrete placements in many places have been in service for over $10-20$ years. The lack of fines aggregates to fill the voids is overcome by the cement paste to be resistant to freeze-thaw cycles due to deicing salt. This property is improved by air entering admixtures, ETA S, ETA S1 and the same.

Traffic loading applications. The anticipated traffic to be carried by a pervious pavement is commonly characterized in terms of equivalent $18,000-\mathrm{lb}(80 \mathrm{kN})$ single-axle load repetitions, which many procedures compute directly based on assumed truck-traffic distributions. Most pervious concrete pavements are used in low-truck-traffic applications. [16]. Currently there are no thickness standards for pervious concrete pavements, but many pervious pavements for parking lots are constructed 6 inches $(150 \mathrm{~mm})$ thick, whereas pervious pavements for low-volume streets have been constructed between 6 and 12 inches (150 and $300 \mathrm{~mm}$ ) thick (ACI 2010).

Apart aforementioned, in designing the pervious concrete consideration should be given to other aspects: Textural aspect, Architectural aspect, Permeability, Sulfate resistance, Abrasion resistance etc.

\subsection{Pervious Concrete Placement}

The production of $\mathrm{PC}$ is not a difficult process, normally it requires additional attention that final product to meet the mix design requirements. Special care should be paid to the water content. In particular, the water content of pervious concrete is limited to a narrow range to provide adequate strength and permeability, and prevent the paste from flowing off the aggregates and closing of the open structure. Transport and placement of PC are done by truck mixers. Other technics of placing are not excluded. Care should be given during the concreting at hot weather conditions and low relative humidity. These two weather factors, affect in the rapid loss of water of concrete and due to this decrease of workability and compressive strength. It is recommended that before concreting the sub base to be sprayed with 
water. Pervious concrete pavement may be placed in either a fixed-form or slip-form paver. Place the concrete from the truck discharge chute near its final position in order to minimize raking and shoveling. Pumping is not recommended due to the zero or low-slump concrete mix. Since pervious concrete has little water in the mix, it should be placed as quickly as possible. While the fresh concrete waits to discharge, it will be hydrating, using valuable water needed for the placing and curing stages. If a fixedform is used, place the concrete approximately $12 \mathrm{~mm}$ higher than the required final elevation with the use of risers along the forms.

After depositing the concrete, quickly bring it to the correct elevation with a rake or other hand straight edge tool. Vibratory screeds are acceptable and encouraged. Caution should be taken to minimize pulling or shoveling the concrete into position, filling the voids or walking on the pervious concrete [10].

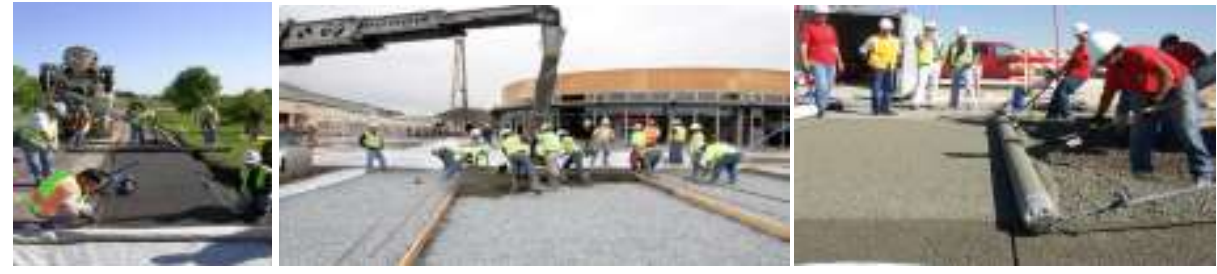

Fig. 6. Placing, roller screeding fresh Pervious Concrete

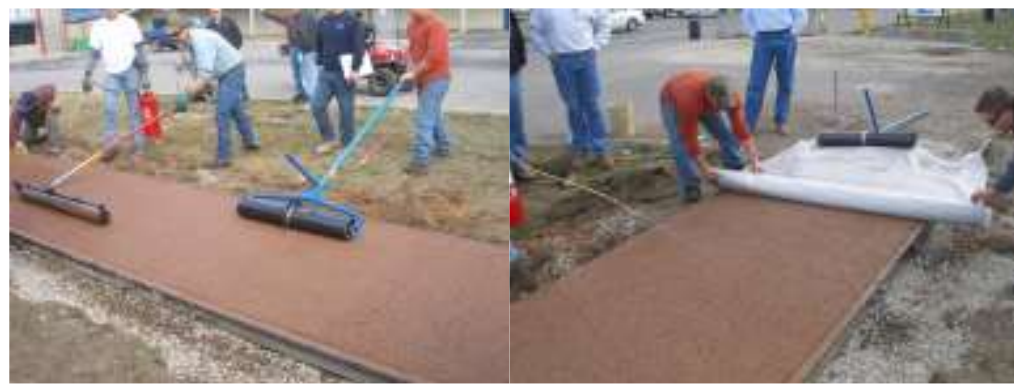

Fig. 7. Joint roller, commonly referred to as a "pizza cutter" and curing (R. Banka)

Finishing. Pervious concrete pavements are not finished in the same manner as conventional pavements. In essence, the final surface finish is achieved as part of the consolidation process, which leaves an open surface. Normal concrete finishing procedures, such as with bull floats and trowels, should not be performed. [6],[10].

Jointing. Jointing is commonly done on pervious concrete to control random crack development. These joints are commonly formed (using a specially designed compacting roller-jointer) to a depth between one-fourth and one-third of the slab thickness. [6].

Curing and protection. After the concrete has been jointed, it is important that the concrete be effectively cured; this is commonly achieved through the placement of thick $0.15 \mathrm{~mm}$ plastic sheeting over all exposed surfaces. The plastic sheeting should be applied no later than 20 minutes following discharge of the concrete, and should remain in place for at least 7 days (longer times may be required under cold weather placement conditions or if supplementary cementations materials are used in the mix). Liquid membrane curing compounds are not commonly used because they prevent surface moisture loss and do nothing to prevent evaporation from within the pervious concrete (Kevern et al. 2009). 


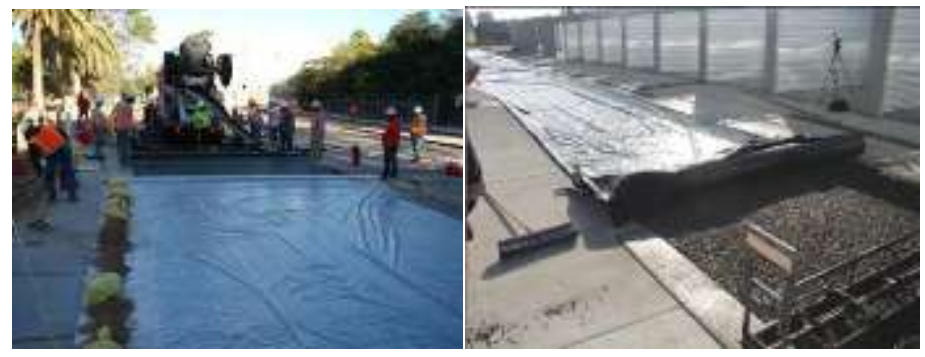

Fig.8. Plastic sheeting should be used to cover the pervious b concrete to prevent moisture loss. (R. Banka)

\section{Maintenance in the service life}

Maintenance of pervious concrete pavement consists primarily of prevention of clogging of the void structure. In preparing the site prior to construction, drainage of surrounding landscaping should be designed to prevent flow of materials onto pavement surfaces.

The two commonly accepted maintenance methods are pressure washing and power vacuuming. Pressure washing forces the contaminants down through the pavement surface. This is effective, but care should be taken not to use too much pressure, as this will damage the pervious concrete. Power vacuuming removes contaminants by extracting them from the pavement voids. The most effective scheme, however, is to combine the two techniques and power vacuum after pressure washing. [1], [10]. [14].
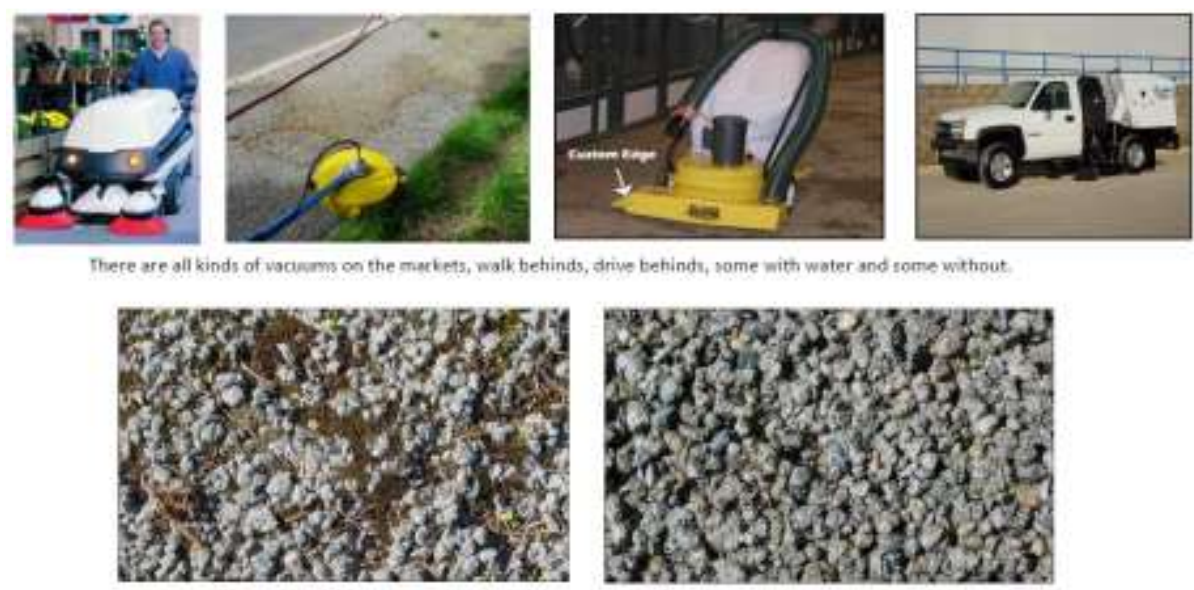

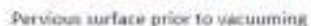

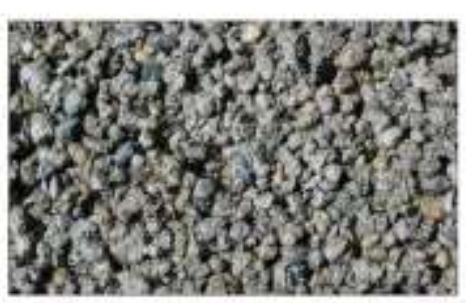

pervious aurfere atter vacuminin

Fig. 9. Maintenance in the life service.

\section{Advantages And Limitations}

Despite many advantages the Pervious Concrete is associated by some disadvantages that limit its applications.

The Table 4, summarizes some of the major benefits and limitations associated with pervious concrete.

As described above, perhaps the most significant benefit provided by pervious concrete is in its use as a storm water management tool. Storm water runoff in developed areas (often the result of or 
exacerbated by the presence of conventional impervious pavement) has the potential to pollute surface and groundwater supplies, as well as contribute to flooding and erosion (Leming et al. 2007) [10].

Pervious concrete can be used to reduce storm water runoff, reduce contaminants in waterways, and renew groundwater supplies. With high levels of permeability, pervious concrete can effectively capture the "first flush" of rainfall (that part of the runoff with a higher contaminant concentration) and allow it to percolate into the ground where it is filtered and "treated" through soil chemistry and biology (Tennis et al. 2004; ACI 2010) [10], [16].

Other major benefits include reduction in heat is land effects (water percolating through the pavement can exert a cooling effect through evaporation, and convective airflow can also contribute to cooling (Cambridge 2005)), reductions in standing water on pavements (and associated hydroplaning and splash/spray potential), and reduced tire-pavement noise emissions (due to its open structure that helps absorb noise at the tire-pavement interface) (ACI 2010).

Along with its many benefits, there are some limitations associated with the use of pervious concrete. First and foremost, pervious concrete has typically been used on lower trafficked roadways, although there are a number of installations on higher volume facilities, and research is being conducted on the structural behavior of pervious concrete slabs (see, for example, Suleiman et al. 2011; Vancura et al. 2011). In addition, pervious concrete exhibits material characteristics (primarily lower paste contents and higher void contents) and produces hardened properties (notably density and strength) that are significantly different from conventional concrete; as a result, the current established methods of quality control/quality assurance (e.g., slump, strength, air content) are in many cases not applicable (ACI 2010). Moreover, a number of special practices, described later, are required for the construction of pervious concrete pavements. And, while there have been concerns about the use of pervious concrete in areas of the country subjected to severe freeze-thaw cycles, available field performance data from a number of projects indicate no signs of freeze-thaw damage (Delatte et al. 2007; ACI 2010).

Table 4. Summary of Pervious Concrete Benefits and Limitations (Tennis et al. 2004; ACI 2010) [16].

\begin{tabular}{|c|c|c|}
\hline & Benefits/Advantages & Limitations/Disadvantages \\
\hline$\checkmark$ & $\begin{array}{l}\text { Effective management of stormwater runoff, } \\
\text { which may reduce the need for curbs and the } \\
\text { number and sizes of storm sewers; }\end{array}$ & Limited use in heavy vehicle traffic area; \\
\hline$\checkmark$ & Reduced contamination in waterways; & $\checkmark \quad$ Specialized construction practices; \\
\hline$\checkmark$ & Recharging of groundwater supplies; & $\checkmark \quad$ Extended curing time; \\
\hline$\checkmark$ & $\begin{array}{l}\text { More efficient land use by eliminating need } \\
\text { for retention ponds and swale; }\end{array}$ & $\begin{array}{l}\checkmark \quad \text { Sensitivity to water content and control in } \\
\text { fresh concrete; }\end{array}$ \\
\hline$\checkmark$ & $\begin{array}{l}\text { Reduced heat island effect (due to } \\
\text { evaporative cooling effect of water and } \\
\text { convective airflow; }\end{array}$ & $\checkmark \quad$ Lack of standardized test methods; \\
\hline$\checkmark$ & $\begin{array}{l}\text { Elimination of surface ponding of water and } \\
\text { hydroplaning potential; }\end{array}$ & $\begin{array}{l}\checkmark \quad \text { Special attention and care in design of some } \\
\text { soil types such as expansive soils and frost- } \\
\text { susceptible ones; }\end{array}$ \\
\hline$\checkmark$ & $\begin{array}{l}\text { Reduced noise emissions caused by tire- } \\
\text { pavement interaction; } \\
\text { Earned LEED }{ }^{\circledR} \text { credits }\end{array}$ & $\begin{array}{l}\checkmark \quad \text { Special attention possibly required with } \\
\text { high groundwater; }\end{array}$ \\
\hline
\end{tabular}

\section{Summary and Future Needs}


From all that it is mentioned so far, the application of Pervious Concrete can be considered as genius finding which in a easy way and practical would avoid negative effects after a heavy rainfall continuing over a long period in both, in Tirana and Prishtina case.

In other countries the use of pervious concrete has increased significantly in the last several years, perhaps largely because it is considered an environmentally friendly, sustainable product. The use of pervious concrete provides a number of benefits, most notably in the effective management of storm water runoff. Other significant benefits include reducing contaminants in waterways, recharging groundwater supplies, reducing heat is land effects, and reducing pavement-tire noise emissions. These are convincing features for applications in our countries.

The benefits of pervious concrete pavements are well known, but concerns over the freeze-thaw resistance may prevent many designers from using pervious concrete in colder climates, which in Tirana Case is of not a matter of concern. Research on freeze-thaw resistance of pervious concrete pavement is ongoing every day. This is in favor of application of PC in Prishtina. Pervious pavements should be placed by experienced installers and the structure and surrounding details should be designed to accommodate the anticipated water flow and drainage requirements.

\section{References}

1. Handbook for Pervious Concrete Certification in Greater Kansas City, CPG Pervious Certification Program.

2. Ashley, E. 2008. "Using Pervious Concrete to Achieve LEED ${ }^{\mathrm{TM}}$ Points." Concrete Infocus. National Ready Mixed Concrete Association, Silver Spring, MD.

3. Obla, K., Ph.D., P.E. Recent Advances in Concrete Technology, 'Pervious Concrete for Sustainable Development”, Sep. 2007, Washington DC.

4. American Concrete Institute (ACI). 2008. Specification for Pervious Concrete Pavement. ACI 522.1-08. ACI, Farmington Hills, MI.

5. American Concrete Institute (ACI). 2010. Report on Pervious Concrete. ACI 522R-10. ACI, Farmington Hills, MI.

6. Kevern, J. T., V. R. Schaefer, K. Wang, and M. T. Suleiman. 2008. "Pervious Concrete Mixture Proportions for Improved Freeze-Thaw Durability." Journal of ASTM International, Vol. 5, No. 2. American Society for Testing and Materials, West Conshohocken, PA.

7. Tennis, Paul D., Leming, Michael L., Akers, David J.. Pervious Concrete Pavements. Engineering Bulletin 302, Portland Cement Association. Skokie, Illinois, 2004.

8. Determinazione dell'indice di abbattimento fotocatalitico degli ossidi di azoto in aria da parte di materiali inorganici fotocatalitici: metodo di prova in flusso continuo. UNI 11247, 2010.

9. Determinazione dell'attività fotocatalitica di leganti idraulici, Metodo della rodammina. UNI 11259, 2008.

10. V.R. Schaefer, K. Wang, M.T. Suleiman, J.T. Kevern. Mix Design Development for Pervious Concrete in Cold Weather Climates. National Concrete Pavement Technology Center, Center for Transportation Research and Education, Iowa State University, 2006.

11. V.R. Schaefer, J.T. Kevern, K. Wang. Pervious Concrete Overlay Design, Construction and Performance.

12. Second International Conference on Sustainable Construction Materials and Technologies, Università Politecnica delle Marche. Ancona, June 2010.

13. K.C. Mahboub, J. Canler, R. Rathbone, T. Robl, B. Davis. Pervious Concrete: Compaction and Aggregate Gradation. ACI Materials Journal, Vol. 106, No.6. November-December 2009.

14. AASHTO Guide for Design of Pavement Structures. American Association of State Highway and transportation Officials, 1993.

15. National Ready Mixed Concrete Association (NRMCA), 2006. Text Reference for Pervious Concrete Contractor Certification. NRMCA, Publication \#2PPCRT. Silver Spring, MD.

16. Watershed Management Institute (WMI). 1997. Operation, Maintenance, and Management of Stormwater Management Systems. Prepared for U.S. Environmental Protection Agency, Office of Water, Washington, DC.

17. W. Arent, Carolinas Ready Mixed Concrete Association, "Pervious Concrete Pavement" 
18. The AdvAnced concreTe PAvemenT Technology (AcPT), TechBrief ACPT DECEMBER 2012 | FHW A-HIF-13-006

19. Pervious Pavement Manual, Florida Concrete and Products Association Inc., Orlando, FL. http://www.fcpa.org.

20. Meininger, R.C., "No-Fines Pervious Concrete for Paving," Concrete International, Vol. 10, No. 8, August 1988.

21. Storm Water Technology Fact Sheet Porous Pavement, United States Environmental Protection Agency, EPA 832-F-99-023, September 1999. www.epa.gov/npdes

22. ACI Committee 522, Pervious Concrete, 522R-06, American Concrete Institute, Farmington Hills, MI, http://www.concrete.org

23. Ghafoori, N., and Dutta, S., "Building and Nonpavement Applications of No-Fines Concrete,".

24. NRMCA, "What, Why, and How? Pervious Concrete," Concrete in Practice series, CIP 38, SilverSpring, Maryland, May 2004, Association (PCA), Skokie, Illinois, 2004.

25. Prof. Erdogan M. Sener, "Porous Concrete Pavement Construction: Opportunity for Alternative Drainage Methodology Emphas is in Construction Education," Indiana University - Purdue University Indianapolis, Spring 2007, American Society for Engineering Education

26. Concrete Technology Today, Portland Cement Association, CT 043, Vo1.25, No.3, Dec 2004. 